\section{US-Sino trade war, a trading setback or an opportunity for emerging markets}

\author{
Ossama Fazal ${ }^{1,}$ Sonia kanwal ${ }^{2}$
}

The Journal of Educational Paradigms

2021, Vol. 03(01) 164-166

(C) Authors

ISSN (Print): 2709-202X

ISSN (Online): 2709-2038

DOI:10.47609/0301042021

\begin{abstract}
After trying to nurture positive diplomatic relationships among two major economies in the world, a cold war has been converted into a trade war between China and the United States of America. Massive tariffs have been imposed on Chinese imports by Trump administration due to which china stroked back with its tariff policy for American products. Different Chinese companies like Huawei and Haier must face unforeseen circumstances due to trade war. The market for Chinese products seems to shrank post trump policy; on one side, it is a major setback for the Chinese market as an emerging market. On the other hand, it is a golden opportunity for other emerging markets like India, Taiwan, Singapore, South Korea, and the Philippines. US-market is a vast market for Chinese electronics, technology, agriculture, leather, furniture, and many more household products since china entered in the race of globalization. A rise in tariff triggered a trade war, resulting in a decrease in Chinese share in US-market. This trade war has offered a golden opportunity for emerging markets to take over Huawei and Haier's market due to trade barriers and bans on them from the US. This paper will study deep-rooted causes of the US-Sino trade war by examining the impact of a trade war on Huawei technologies and Haier; big Chinese firms dealing worldwide and have a large share in the US-market. The research type will be exploratory, and most of the data is based on secondary data sources. It has been found in this article that the US-Sino trade war is causing losses to both economies on international trade forum. The products from other Asian countries are replacing the Chinese products in the USA. On the other hand, the emerging markets like India, Hong Kong, South Korea, and Taiwan benefit from the absence of Chinese products from the international market. Hence, the winner of the US-Sino trade wars is emerging economies.
\end{abstract}

Keywords: Trade war, US-Sino trade war, Protectionism, Emerging markets

A trade war is initiated when a nation imposes quotas, tariffs, and imports from other nations. Simultaneously foreign countries strike back with some self-protection approach. When this situation escalates, it reduces international trade, and the intensity of trade war is increased. The United States of America and China have imposed tariff barriers on each other's imports. The Sino-US trade war affected the bulk of imports in electronics, machinery, and Information technology products. The Chinese giant telecommunication industry Huawei Technologies and home appliance manufacturer Haier are among the most affected companies due to this escalating trade war. At the same time, this trade war can be a golden opportunity for emerging markets like India, Taiwan, Singapore, South Korea, and the Philippines, to fill up the gap created by the unavailability of the Chinese goods.

Trade is a mainly economic concept (Allais, BalassaTrent, Romney, \& Wonnacott, 2019). that involves buying and selling goods for some consideration paid by the buyer to the seller, which ultimately consists of transferring ownership transfer from the seller to buyer (Gray \& Martin, 1980). Trade can be on the national level as well as on the international level. Through international trade, countries can expand their market (Hayes, 2019). Peace is the natural effect of trade between the two countries. Two nations involved in a trade transaction are interdependent (De Montesquieu, 1989). Globalization acted as the catalyst for the global trade process throughout the globe. The primary purpose of globalization is to minimize war activity among countries after World War II. Does the wave of globalization soothe worldwide relations? Rise in the trade flows and expansion of free markets worldwide that undoubtedly pacify the war, but it also triggered another war named trade war among different nations (Martin, Mayer, \& Thoenig, 2008). There is a risk factor attached to uncertain trading among nations. Two approaches are used to minimize the trade risks; defensive strategies and preventive (selfprotection) approach. The self-protection approach is the reason for the trade war $(\mathrm{Wu}, 2005)$. A trade war is initiated when a nation imposes quotas, tariffs, and duty on imports from other nations. Simultaneously foreign countries strike back with the same sort of self-protection approach. When this situation escalates, it reduces international trade, and the intensity of trade war increases (Amadeo, 2019). Nations are involved in improving imports and exports in their own country. World's two largest economies officially began trade war on a Friday morning when the White House announced the threats of imposing tariffs on $\$ 34$ billion worth of Chinese goods. Escalation of this trade war can harm numerous companies and consumers in both countries (Swanson, 2018).

The Sino-US trade war affected the bulk of imports in sectors like electronics, machinery, and Information technology products. The electronics industry and optical equipment, including televisions, sound, and recording devices, had almost half of the drop in the US import from China. Sales of consumer products like furniture, fishery industry, vehicles, and different leather articles had dropped due to imposed tariffs from US administration. The consequences of this escalating US-Sino trade war affect the other

${ }^{12}$ UCP Business School, Faculty of Management Studies, UCP, Lahore. Corresponding author Email: Sonia.kanwal43@ gmail.com 
nations who are directly or indirectly involved with these two nations. Major products are now being imported from East Asian markets, which lead to the diversion of investment from China to East Asian countries. This diversion is a strategy to by-pass the US hiked tariff policy (Rosyadi \& Widodo, 2018).

A matter of serious concern has been emerged because of the eruption of the escalating trade war between two giant economic players as there is no chance of halting it (Mor, 2018). The SinoUS trade disputes are engulfing the different important emerging industries in the IT sector, affecting the trade balance of the world. Both sides are stuck to the hard-hitting positions with every move counter-attacked from both sides (Brar, 2018). The present trade dispute between China and the US are not new or merely the fruits of economic differences or rivalry. There is a profound reason for this trade war, and it is based on the deep cleavage due to the geopolitical and geo-economic power (Johnston \& Stockmann, 2007).

This protectionist tit-for-tat strategy could have drastic results for both nations as per the Great Depression (Cusack \& McDonald, 1997). The results are not limited to the two countries. Its reverberations are spreading all over the world. GDP in China has been reduced by $-1.41 \%$ and in US $-1.35 \%$. All sectors in imports and exports had been affected by trade disputes. When global value chain (GVC) is accounted for, the negative impact of this bilateral trade is spreading across the nation all over the world, which leads to a decrease in the world GDP by - \$US 450 billion (Itakura, 2019).

Huawei suffers from a decrease in market share and revenue. Huawei Technologies, the Chinese telecom giant, was an apple of investor's eyes till June 2019, when Trump administration banned the company through allegations of espionage. Huawei today us the centerpiece of escalating the US-Sino trade war. This ban is that American people are thinking of connections between Huawei and the Chinese government (Inkster, 2019). The privacy concerns were severe or not, but last year Huawei surpassed the second largest telecom service and product provider, Apple, Inc., for the very first time in history. Still, Samsung Electronics Co. Inco is the number one smartphone provider. Since its formation in 1987, Huawei technologies are blooming every year in four domains; telecom, IT, smartphones and devices, and cloud service. Huawei has generated \$104 billion in 2019. But due to ban and espionage allegations, the sales of Huawei for Q2 had impacted. Huawei espionage allegation had been developed since 2012 that the company is spying for the Chinese government. In July 2018, other countries like the UK, New Zealand, Australia, had shown security concerns and excluded Huawei from 5G networks technology (Cain, 2013). Us has put many trade restrictions on Huawei, and the company is not allowed to recruit any employee anymore in the US. Google's Huawei license is canceled, and 90 days were allotted to Google for telling customers that its services will no longer be available to the customers. It is quite clear that Huawei's future depends upon the future of the trade war (Ciuriak, 2019).

Haier is divesting from US-firms.

Haier is a Chinese electronics company selling home appliances all over the world. After the US-Sino trade war, Haier decided to stop exportin home appliance goods to the US, as the consumer has to pay extra money due to tariff barriers (Chen, Lin, Li, \& Chen, 2004). Haier is a Chinese company, is selling nearly $5 \%$ of appliances in the US under the name of GE Appliance; a project of Qingdao Haier Company. The US-based manufactured home appliances of the American white goods units, acquired by Haier, are now at a halt. The Chinese company is negotiating with the US government over tariff policy (Jaskuła).

The US-Sino trade war is an opportunity for emerging markets

The US-Sino trade war is a major setback for world economics; however, it can expand markets and investment by emerging markets like Taiwan, Singapore, Thailand, India, south and, Malaysia, etc. (Li, He, \& Lin, 2018). The US-China trade war is making big giant companies in China shift their supply chain activities; they must turn their manufacturing plants out of China. If we are talking about manufacturing plants, it is directly related to cheap labor, which is only available in emerging countries after China. Most of the industry, especially the stages of final assembly and shifting, plan to shift their plants out of China. For example, the American business-to-business manufacturing platform Sourcify moved its factories to India, Bangladesh, Vietnam, the Philippines, and Mexico. The revenues of emerging economies, more specifically of ASEAN countries, were gradually increasing and forecasted to be raised in 2020, as shown in figure 1 (KIYOSHI KUSAKA, 2018).

Most apparel manufacturers have shifted their plants from China to other low-wage countries like Bangladesh, Thailand, and India. ASEAN countries are at benefit due to US-Sino trade, as the shifting of supply chain activities according to geographical conditions, the near economic source of resources will be a good option for the investors; ASEAN countries. Hence, the biggest winner of the US-Sino trade will be ASEAN countries (Aslam, 2019). In November, the emerging markets ETF has risen by $0.9 \%$. However, China's composite index fell up to $0.8 \%$. The exchange rates of ASEAN countries are also showing the positive impact of the US-Sino trade war on ASEAN, as shown in figure 2 (KIYOSHI KUSAKA, 2018). This is a victory of emerging markets as they avail the opportunity and fill up the Chinese firms' gap in global trade due to trade war (Lau, 2018; Li et al., 2018).

\section{Findings}

In a nutshell, it can be said that the US-Sino trade war is a setback for global trade, consumers, and both countries, as it lowers their export sales. China is a prominent supplier of goods at each level to the US market. Due to tariff bans, now the Chinese goods are of double prices in the US. Consumers are thinking of shifting from the Chinese goods to other country's goods, to lower their cost. Investors are adopting the same thinking in China. They have started divestment and relocating their supply chain activities out of China under a low-cost strategy. Hence, it can be said that the US-Sino war is a golden opportunity for other emerging markets to expand their activities and fill up the gap created by the unavailability of Chinese goods. In the US-Sino trade war, the victory in terms of investment, revenues, and market share of emerging markets. 


\section{References}

Allais, M., BalassaTrent, B., Romney, J. B., \& Wonnacott, R. (2019). International trade. Encyclopadia Britannica. Retrieved from https://www.britannica.com/topic/international-trade

Amadeo, K. ( 2019). Trade Wars and their Effect on the Economy and You. The balance. Retrieved from https://www.thebalance.com/trade-wars-definition-how-itaffects-you-4159973

Aslam, M. (2019). US-China trade disputes and its impact on ASEAN. Transnational Corporations Review, 11(4), 332-345.

Brar, J. (2018). Factors in the Eruption and Persistence of Sino-US Trade War. Sino-US Trade War: A New Challenge to Globalisation, 22.

Cain, F. (2013). Economic statecraft during the Cold War: European responses to the US trade embargo: Routledge.

Chen, J. C., Lin, B., Li, L., \& Chen, P. S. (2004). Logistics management in China: A case study of Haier. Human Systems Management, 23(1), 15-27.

Ciuriak, D. (2019). A trade war fuelled by technology. Opinion, January, 11.

Cusack, J., \& McDonald, H. (1997). UVF: Poolbeg Press.

De Montesquieu, C. (1989). Montesquieu: The spirit of the laws: Cambridge University Press.

Gray, H. P., \& Martin, J. P. (1980). The meaning and measurement of product differentiation in international trade. Review of World Economics, 116(2), 322-329.

Hayes, A. (2019, Jun 7, 2019). Trade S Updated ECONOMICS. Retrieved from https://www.investopedia.com/terms/t/trade.asp

Inkster, N. (2019). The Huawei Affair and China's Technology Ambitions. Survival, 61(1), 105-111.

Itakura, K. (2019). Evaluating the Impact of the US-China Trade War. Asian Economic Policy Review.

Jaskuła, P. THE REDEFINITION OF FOREIGN POLICY OF THE US SINCE TRUMP'S ELECTION. THE CASE OF TRADE WAR WITH CHINA.

Johnston, A. I., \& Stockmann, D. (2007). Chinese attitudes toward the United States and Americans. Anti-Americanisms in world politics, 157-195.

Kiyoshi Kusaka. (2018). ASEAN growth forecasts take hits from trade war and market turmoil Survey of economists reveals fears for exports and currencies over long haul. ECONOMY. Retrieved from https://asia.nikkei.com/Economy/ASEANgrowth-forecasts-take-hits-from-trade-war-and-market-turmoil

Lau, L. J. (2018). A better alternative to a trade war. China and the World, 1(02), 1850014.

Li, C., He, C., \& Lin, C. (2018). Economic impacts of the possible China-US trade war. Emerging Markets Finance and Trade, 54(7), 1557-1577.

Martin, P., Mayer, T., \& Thoenig, M. (2008). Make trade not war? The Review of Economic Studies, 75(3), 865-900.

Mor, S. (2018). US-China trade war: Learning by doing. Culture of Learning and Experimentation for Well-Being, 184-190.

Rosyadi, S. A., \& Widodo, T. (2018). Impact of donald trump's tariff increase against Chinese imports on global economy: Global trade analysis project (GTAP) model. Journal of Chinese
Economic and Business Studies, 16(2), 125-145. doi:10.1080/14765284.2018.1427930

Swanson, A. (2018). Trump's trade war with china is officially underway. Retrieved from https://www.nytimes.com/2018/07/05/business/china-us-tradewar-trump-tariffs.html

Wu, J. P. (2005). Trade Agreements as Self-Protection. Review of International Economics, 13(3), 472-484.

Appendix

\begin{tabular}{|c|c|c|c|c|c|c|c|c|c|}
\hline & \multicolumn{3}{|c|}{2018} & \multicolumn{2}{|c|}{2019} & \multirow[t]{2}{*}{2017} & \multirow[t]{2}{*}{2018} & \multirow[t]{2}{*}{2019} & \multirow[t]{2}{*}{2020} \\
\hline & Q2 & Q3 & Q4 & Q1 & $\mathbf{Q 2}$ & & & & \\
\hline ASEANS & 5.2 & $\begin{array}{c}5.0 \\
(4.8)\end{array}$ & $\begin{array}{c}4.8 \\
(4.9)\end{array}$ & $\begin{array}{c}4.8 \\
(4.8)\end{array}$ & 4.7 & 5.0 & $\begin{array}{c}4.9 \\
(5.0)\end{array}$ & $\begin{array}{c}4.8 \\
(5.0)\end{array}$ & $\begin{array}{c}4.8 \\
(5.0)\end{array}$ \\
\hline Indonesia & 5.3 & $\begin{array}{c}5.3 \\
(5.3) \\
\end{array}$ & $\begin{array}{c}5.2 \\
(5.3)\end{array}$ & $\begin{array}{c}5.2 \\
(5.3)\end{array}$ & 5.2 & 5.1 & $\begin{array}{c}5.2 \\
(5.3)\end{array}$ & $\begin{array}{c}5.3 \\
(5.5) \\
\end{array}$ & $\begin{array}{c}5.5 \\
(5.7)\end{array}$ \\
\hline Malaysia & 4.5 & $\begin{array}{c}4.8 \\
(5.2)\end{array}$ & $\begin{array}{c}4.8 \\
(5.0)\end{array}$ & $\begin{array}{c}4.6 \\
(5.0)\end{array}$ & 4.8 & 5.9 & $\begin{array}{c}4.9 \\
(5.3)\end{array}$ & $\begin{array}{c}4.6 \\
(5.0)\end{array}$ & $\begin{array}{c}4.6 \\
(4.8)\end{array}$ \\
\hline Philippines & 6.0 & $\begin{array}{c}6.4 \\
(6.8)\end{array}$ & $\begin{array}{c}6.6 \\
(6.9)\end{array}$ & $\begin{array}{c}6.6 \\
(6.9)\end{array}$ & 7.0 & 6.7 & $\begin{array}{c}6.4 \\
(6.8)\end{array}$ & $\begin{array}{c}4.6 \\
(5.0)\end{array}$ & $\begin{array}{c}6.8 \\
(6.8)\end{array}$ \\
\hline Singapore & 3.9 & $\begin{array}{c}2.2 \\
(2.0)\end{array}$ & $\begin{array}{c}2.2 \\
(2.5)\end{array}$ & $\begin{array}{c}2.7 \\
(2.8)\end{array}$ & 2.5 & 3.6 & $\begin{array}{c}3.1 \\
(3.1)\end{array}$ & $\begin{array}{c}6.7 \\
(7.0)\end{array}$ & $\begin{array}{c}2.3 \\
(2.4)\end{array}$ \\
\hline Thailand & 4.6 & $\begin{array}{c}4.3 \\
(4.3)\end{array}$ & $\begin{array}{c}4.4 \\
(4.3)\end{array}$ & $\begin{array}{c}3.9 \\
(3.8)\end{array}$ & 4.0 & 3.9 & $\begin{array}{c}4.6 \\
(4.4)\end{array}$ & $\begin{array}{c}2.6 \\
(2.8)\end{array}$ & $\begin{array}{c}4.0 \\
(4.2)\end{array}$ \\
\hline India & 8.2 & $\begin{array}{c}7.3 \\
(7.3)\end{array}$ & $\begin{array}{c}7.0 \\
(7.1)\end{array}$ & $\begin{array}{c}6.9 \\
(7.2)\end{array}$ & 7.1 & 6.7 & $\begin{array}{c}7.4 \\
(7.4)\end{array}$ & $\begin{array}{c}7.6 \\
(7.5)\end{array}$ & $\begin{array}{c}7.9 \\
(7.7) \\
\end{array}$ \\
\hline China & 6.7 & $\begin{array}{l}6.6 \\
(--)\end{array}$ & $\begin{array}{c}--(-- \\
)^{--}\end{array}$ & $\begin{array}{c}--(-- \\
-(-\end{array}$ & -- & 6.9 & $\begin{array}{c}6.6 \\
(6.6)\end{array}$ & $\begin{array}{c}6.3 \\
(6.3)\end{array}$ & $\begin{array}{c}6.2 \\
(6.2)\end{array}$ \\
\hline
\end{tabular}

Figure 1: Economic growth forecast for ASEAN countries (KIYOSHI KUSAKA, 2018)

\begin{tabular}{|c|c|c|c|c|c|c|c|}
\hline & \multicolumn{3}{|c|}{$\begin{array}{l}\text { Exchange rate } \\
\text { (Currency units per dollar) }\end{array}$} & \multicolumn{4}{|c|}{$\begin{array}{l}\text { Interest rate** } \\
\text { (in percent) }\end{array}$} \\
\hline & $\begin{array}{l}\text { Dec. } \\
2007\end{array}$ & $\begin{array}{l}\text { Sept. } \\
2018\end{array}$ & $\begin{array}{l}\text { Dec. } \\
2018^{*}\end{array}$ & $\begin{array}{l}\text { Dec. } \\
2017\end{array}$ & $\begin{array}{l}\text { Sept. } \\
2018\end{array}$ & De & $2018 *$ \\
\hline India & 63.9 & 72.5 & $\begin{array}{l}71.6 \\
(68.5)\end{array}$ & 6.00 & 6.50 & $\uparrow$ & $\begin{array}{l}6.65 \\
(6.42)\end{array}$ \\
\hline Indonesia & 13,548 & 14,929 & $\begin{array}{l}14,703 \\
(14,005)\end{array}$ & 4.25 & 5.75 & 个 & $\begin{array}{l}5.96 \\
(5.25)\end{array}$ \\
\hline Malaysia & 4.06 & 4.14 & $\begin{array}{l}4.11 \\
(3.96) \\
\end{array}$ & 3.00 & 3.25 & $\boldsymbol{1}$ & $\begin{array}{l}3.25 \\
(3.29) \\
\end{array}$ \\
\hline Philippines & 49.9 & 54.3 & $\begin{array}{l}53.6 \\
(52.9) \\
\end{array}$ & 3.00 & 4.50 & & $\begin{array}{l}4.53 \\
(3.72)\end{array}$ \\
\hline Singapore & 1.34 & 1.37 & $\begin{array}{l}1.36 \\
(1.35)\end{array}$ & 1.50 & 1.64 & 个 & $\begin{array}{l}1.81 \\
(1.88)\end{array}$ \\
\hline
\end{tabular}

Figure 2: Exchange rate growth for ASEAN countries (KIYOSHI KUSAKA, 2018) 